\title{
IMPLEMENTASI NILAI-NILAI AGAMA HINDU TERHADAP PENYELESAIAN TINDAK PIDANA ADAT DI BALI
}

\author{
Oleh: \\ Putu Rizky Sitraputra
}

\begin{abstract}
Research on the implementation of the values of Hinduism to the completion of customary criminal acts in Bali. Most of the population adheres to Balinese Hinduism, daily activities always adhered to the concept of Tri Hita Karana, which in turn is continuously executed. Human relationships with others based on the nature of mind that is communal or kinship based pleh soul. To set the level of a good life together customs regulations grow and develop with imbued the values of Hinduism. Customary rules and formulate actions that are required, allowed or prohibited as village members must perform the obligations to the village, prohibition for people who are dirty entering the sacred area. Incestuous copulation cases which occurred in Bali only charged criminal under national law alone. Actually, should also be reviewed from the local community sector appropriate sanctions in order to satisfy the sense of justice. The values of Hinduism derived from Hindu law aims to balance the natural result of gross misconduct perpetrator intercourse, judicial practice provides an opportunity for the judge to impose sanctions customary in accordance with Law number 48 of 2009, which states the court in addition must contain reasons and grounds of this decision, as well must contain a specific article of the source of unwritten law that formed the basis for the judge. Hindu religious values in the practice of judicial consideration by the judge and the efforts made in the traditional village of indigenous criminal offense. The method used is empirical research methods to conduct field research in which cases occur. The procedure for sampling used is purposive sampling. The data is processed and analyzed qualitatively. The results showed that the judicial practice in cases of promiscuity in state court Amlapura not consider matters relating to the values of Hinduism. Efforts made in the traditional village settlement gamia gamana customs offense is to apply awig awig traditional village or Paruman each indigenous villages.
\end{abstract}

Key Words : Customs, Hindu religion, Pakraman Village

\section{PENDAHULUAN}

\subsection{Latar Belakang}

Kehidupan agama hindu di bali sangat unik dan kompleks. Hampir setiap bidang kehidupan umatnya diresapi oleh nilai-nilai ajaran agama hindu. Sehingga kadangkadang agak sulit untuk membedakan dan memisahkan antara pelaksanaan kehidupan beragama dan adat-istiadat. Sebagaimana diketahui bersama agama mempunyai sifat universal dan sifat subjektif serta sensitif yang beralaskan pada suatu kepercayaan dan keyakinan serta sulit diterima oleh pemikiran yang ilmiah. Warga masyarakat hindu di bali sejak turun temurun sudah mengenal hubungan antara tuhan, manusia serta manusia dengan manusia lainnya, serta manusia dengan makhluk hidup lainnya. Keterkaitan hubungan antara ketiga komponen ini diyakini memberikan keseimbangan hidup secara nyata. ${ }^{1}$

I Gusti Ketut Sutha, 1987, Bunga Rampai Beberapa Aspek Hukum Adat, Liberty, Yogyakarta, hlm.2. 
Hubungan antara pencipta, manusia, dan tumbuhan lama-kelamaan dijadikan pedoman hidup dan kebiasaan yang akan menumbuhkan kesadaran bersama untuk menjaga dan melestarikan keseimbangan yang sudah baik ini. Ketika ada gangguan seperti pembunuhan, pencurian, dan pencabulan yang merupakan tindak pidana umum oleh masyarakat bali dilakukan ritual upacara agar kondisi alam bisa kembali seperti semula. Berbeda dengan KUHP yang menyatakan setiap delik yang dilakukan dikenakan pidana penjara dan denda untuk membuat jera pelaku kejahatan. Seorang kriminal menurut hukum agama hindu, tidak begitu dipedulikan melainkan hasil dari perbuatan pidananya yang dituntut pertanggungjawaban. ${ }^{2}$

Berdasarkan ajaran agama hindu ada tiga kerangka dasar yang terjalin dalam satu kesatuan yaitu : Falsafah, Etika, Ritual. Kerangka dasar tersebut harus dipegang dan petunjuk bagi umat beragama hindu. Selain ketiga kerangka dasar tersebut agama hindu juga mempunyai kepercayaan yang mutlak yang disebut panca sradha yakni : Percaya dengan adanya sang hyang widhi, percaya dengan adanya atma, percaya dengan karmaphala, percaya denga reinkarnasi, percaya dengan moksa (kebahagian yang kekal).

Kenyataan ini memberikan suatu gambaran bahwa secara langsung ajaran agama turut memberikan warna dan corak terhadap perikelakuan masyarakat dalam kehidupan adat. Pertumbuhan hukum adat sudah tentu didukung oleh rasa keadilan dari masyarakat yang kemudian menjelmakan apa yang semula dinamakan adat istiadat,

I Made Widnyana, 1993, Kapita Selekta Hukum Pidana Adat, Eresco, Bandung, hlm.5. yang secara terus menerus dipelihara, sehingga menghasilkan kepastian hukum didalam penerapannya pada kehidupan sehari-hari. Kepastian tersebut lahir bukan semata-mata diterapkan secara terus menerus didalam kehidupan sehari-hari akan tetapi lebih dari itu yaitu merupakan adat-istiadat yang kemudian menjadi kaidah hukum yang mampu memberikan jaminan dalam mengatur masyarakat pendukungnya. Hakim dalam memutuskan suatu perkara sangat bergantung pada ketentuan pasal 10 KUHP yakni pidana mati, pidana penjara, pidana kurungan, pidana denda. Ketentuan pidana tersebut tidak memperhatikan kepentingan masyarakat atau dalam hal ini kepentingan dari korban.

Masyarakat di kehidupan sehariharinya apabila ada seseorang melakukan pelanggaran dan yang menyebabkan kerugian dari pihak korban maka wajib orang yang melakukan perbuatan tersebut untuk dikenakan hukuman termasuk membayar ganti kerugian sebesar yang diminta oleh korban. Praktek di pengadilan walaupun diberikan dasar oleh undang-undang darurat 1 tahun 1951, hakim diharapkan berani menggali hukum yang berkembang di masyarakat yakni hukum pidana adat, tetapi kasus-kasus yang menurut hukum yang hidup di masyarakat sebenarnya masih dianggap sebagai hal yang dapat dituntut pidana. Berarti hakim lebih cenderung untuk berpegang teguh pada asas legalitas. Hal ini dapat dilihat pada kasus gamia gemana di singaraja.

\subsection{Rumusan Masalah}

1. Apakah hakim mempertimbangkan nilai-nilai agama hindu dalam praktek peradilan? 
2. Upaya-upaya apa yang dilakukan desa adat dalam penyelesaian tindak pidana adat di Bali?

\subsection{Tujuan Penelitian}

Tujuan dari disusunnya tulisan ini adalah untuk mengetahui hakim mempertimbangkan nilai-nilai agama hindu dalam praktek peradilan dan upaya-upaya yang dilakukan desa adat dalam penyelesaian tindak pidana adat di Bali.

\section{Metode Penelitian}

Dalam penelitian ini penulis menggunakan metode penelitian yuridis empiris. Penelitian yuridis empiris bertujuan untuk mempelajari peraturan perundangundangan yang dipergunakan dalam menangani kasus delik adat Gamia Gemana, dengan melakukan penelitian ke lapangan dimana kasus tersebut terjadi. Jenis data yang digunakan dalam penelitian ini adalah data lapangan dan data kepustakaan. Data kepustakaan diinventarisasi dari bahanbahan hukum primer, dan bahan hukum sekunder. Data lapangan dilakukan dengan observasi didaerah sampel.

Teknik penentuan sampel yang digunakan adalah teknik non probability sampling yaitu tidak semua subyek atau individu mendapat kemungkinan yang sama untuk dijadikan sampel. Jenis teknik non probabilty sampling yang digunakan dalam penelitian ini adalah Purposive Sampling, berdasarkan penjajakan awal penelitian dilakukan di desa sudaji, kabupaten buleleng. Teknik pengumpulan data yang digunakan berupa kepustakaan yakni catatan-catatan dari hasil penelitian, hasil karya pakar hukum yang dikumpulkan melalui studi dokumen dan wawancara bersumber dari tokoh-tokoh adat masyarakat desa setempat. Pengolahan dan analisis data secara analisis kualitatif yaitu suatu uraian yang mengandung suatu analisi secara sistematis logis. ${ }^{3}$

\section{HASIL DAN PEMBAHASAN \\ 3.1 Tinjauan Yuridis}

Pidana adalah suatu penderitaan yang diberikan kepada pelaku kejahatan yang dijatuhkan oleh kekuasan yang berwenang untuk menjatuhkan pidana atas nama negara sebagai penanggungjawab dari ketertiban hukum umum terhadap pelanggaran norma. Tindak pidana menurut, Wirjono Prodjodikoro mengunakan berarti suatu perbuatan yang pelakunya dapat dikenai pidana. Begitu pula Sudarto, mengatakan bahwa "penghukuman" berasal dari kata dasar "hukum" sehingga dapat diartikan sebagai menetapkan hukuman atau memutuskantentanghukumnya. Menetapkan hukum untuk suatu peristiwa tidak hanya menyangkut bidang hukum pidana saja, tetapi juga menyangkut hukum perdata. ${ }^{4}$

Pengetian adat adalah kebiasaankebiasaan yang sering dijumpai didalam masyarakat, dijadikan pedoman untuk berprilaku sehingga apabila terdapat perilaku yang menyimpang dan menyebabkan kekacauan dapat dikenai sanksi sesuai dengan daerah setempat. ${ }^{5}$

Soepomo menjelaskan adat dikatakan hukum apabila di ukur dari rasa hukum tradisional dan merupakan hukum yang

Amirudin dan Zaenal Asikin, 2006, Pengantar Metode Penelitian Hukum, PT. Raja Grafindo Persada, Jakarta, hlm.26,

4 Sudarto, 2003, Hukum Pidana, Alumni Cet. 4, Bandung, hlm.7.

Satjipto Rahardjo, 1998, Pengertian Hukum Adat, Hukum yang Hidup dalam Masyarakat, Binacipta, Bandung, hlm.23. 
hidup karena penjelmaan perasaan hukum yang nyata dari para rakyat. Pidana adat merupakan suatu reaksi adat dari tiap-tiap gangguan keseimbangan yang melanggar rasa keadilan dan kepatutan yang hidup dimasyarakat dengan kewajiban pemulihan kembali suatu keadaan menjadi normal. ${ }^{6}$

\subsection{Pertimbangkan Nilai-Nilai Agama Hindu Dalam Praktek Peradilan}

Hukum pidana adat juga mempunyai sumber hukum sama dengan bidang hukum lainnya. sumber hukum adalah tempat dimana kita dapat menemukan hukum dan mempengaruhi isi hukum. Sumber hukum tidak tertulis adalah kebiasaankebiasaan yang ditaati oleh masyarakat adat yang bersangkutan dari sejak dulu hingga sekarang dan berkelanjutan. Sumber hukum tertulis dari hukum pidana adat adalah peraturan-peraturan yang dituliskan seperti sastra dresta (kitab-kitab agama), paswara (keputusan) MDP, Parisadha Hindu Dharma, karya-karya ilmiah tokoh-tokoh agama. ${ }^{7}$

Kasus-kasus persetubuhan sedarah pernah terjadi di bali dan penyelesaiannya dalam praktek peradilan hanya menggunakan Pasal 294 ayat (1) KUHP yang menyatakan "barangsiapa melakukan perbuatan cabul dengan anaknya, tirinya, anak angkatnya, anak di bawah pengawasannya yang belum dewasa yang pemeliharaannya, pendidikan atau penjagaannya diserahkan kepadanya atau dengan bujangnya atau bawahannya yang belum dewasa, diancam dengan pidana penjara paling lama tujuh tahun".

Soepomo, 1983, Bab-Bab Tentang Hukum Adat, Pradnya Paramita, Jakarta, hlm.43.

Wayan P. Windia dan Ketut Sudantra, 2006, Pengantar Hukum Adat Bali, Lembaga Dokumentasi dan Publikasi Fakultas Hukum Universitas Udayana, Denpasar, hlm.3.
Ajaran agama hindu yang tertuang dalam manawa dharmasastra pasal 171 dan 17, buku XI menyatakan "ia yang telah melakukan hubungan badan dengan wanita saudara kandungnya, dengan wanita belum kawin, dengan istri teman atau dengan istri anak yang melanggar tempat tidur diwajibkan melakukan tapa". Pasal berikutnya menyatakan "ia berhubungan dengan anak dari saudara perempuan ayah, yang hampir sama dengan saudara perempuan ibu atau anak dari saudara laki ibu, disucikan dengan melakukan tapa bulan". Delik adat seperti yang tertuang dalam penjelasan kitab tersebut disebut gamia gamana. ${ }^{8}$

Delik adat gamia gamana ini pernah terjadi di desa sudaji, kecamatan dawan yakni seorang ayah yang bernama GPY tega menghamili anak kandungnya sendiri bernama LY yang masih duduk di bangku SMA. Kejadian tersebut terpergok saat LY memeriksakan diri pada bidan di kota singaraja oleh warga bernama I Kadek Fajar. Selama ini LY tinggal bersama ayahnya saja sekitar lima tahun yang lalu, karena ibunya juga pernah dihamili ayahnya tanpa dinikahi. Keterangan kelian desa pakraman sudaji, bapak Sunuada bahwa kejadian tersebut telah membuat leteh (kotor) desa dan harus dibersihkan sehingga keduanya dikenakan sanksi adat berupa upakara mepepada dan mecaru labuh gentuh. Apabila tidak sanggup melaksanakan upakara tersebut yang bersangkutan akan di kasepekang (keluarkan dari desa), biaya upacaranya sendiri sebesar Rp. 60.000.000,- (enam puluh juta rupiah) harus dibayarkan oleh GPY dan desa adat yang melaksanakannya. Kasus persetubuhan

I Gede Pudja dan Tjok Rai Sudharta, 1978, Manawa Dharma Sastra (Manawa Dharmacastra, Ditjen Bimas Hindu dan Budha, Jakarta, hlm.21. 
sedarah ini hanya diselesaikan secara adat tanpa adanya proses hukum.

Melihat peranan sanksi adat lebih penting dari hukum pidana nasional yang termuat dalam Kitab Undang-Undang Hukum Pidana berarti pemidanaan nasional tidak efektif dan memberikan rasa keadilan. Menurut ketentuan Rancangan KUHP 2012, Pasal 54 ayat (1) dan (2) termuat ide keseimbangan yakni menyelesaikan konflik yang ditimbulkan oleh tindak pidana, memulihkan keseimbangan, dan mendatangkan rasa damai dalam masyarakat. Pemidanaan merupakan suatu proses dan sebelum proses berjalan, karenanya peranan hakim sangat penting sekali. Ia merumuskan sanksi pidana yang terdapat dalam suatu peraturan dengan menjatuhkan pidana bagi terdakwa dalam kasus tertentu.

Sebagaimana diketahui putusan PN Amlapura Nomor 34/Pid.B/1994/PN.AP menyatakan terdakwa I Wayan Raka terbukti secara sah dan meyakinkan bersalah melakukan tindak pidana "perbuatan cabul dengan anak kandungnya, anak tirinya, anak pungutnya yang dibawah pengawasannya belum cukup umur". Menghukum terdakwa tersebut oleh karenanya dengan pidana penjara selama : 1 (tahun) 3 (bulan). Dengan pertimbangan hakim menurut unsur-unsur perbuatan pidana yang terkandung dalam Pasal 294 ayat (1) KUHP yakni:

- Barang siapa pada dasarnya menunjuk pada subyek hukum atau pelaku tindak pidana, dimana subyek hukum dimaksud adalah orang perorangan yang dipandang mampu bertanggungjawab secara hukum atas perbuatannya tersebut

- Melakukan perbuatan cabul menunjuk pengertian segala perbuatan yang melanggar kesusilaan atau kesopanan persetubuhan termasuk pula dalam pengertian perbuatan cabul

Dengan anaknya yang belum dewasa mengandung pengertian anak yang pada saat kejadian persetubuhan berlangsung baru berusia 17 tahun dalam hal mana usia tersebut merupakan anak yang belum dewasa.

\subsection{Upaya-Upaya yang Dilakukan desa adat dalam penyelesaian tindak pidana adat di Bali}

Penyelesaian delik adat yang berakibat terganggunya keseimbangan keluarga atau masyarakat, walaupun adakalanya perkaranya sampai ditangani oleh alat negara, dapat ditempuh dengan cara melalui pribadi dan atau keluarga yang bersangkutan atau ditangani kepala kerabat, kepala adat, kepala desa, dan alat negara. ${ }^{9}$

Apabila terjadi delik adat dan kepadanya dimintakan penyelesaiannya oleh pihak warga desanya yang mengadu, maka kepala desa adat dapat menyelenggarkan peradilan desa bertempat di balai desa. Untuk keperluan itu ia akan berusaha antara lain :

Menerima dan mempelajari pengaduan yang disampaikan kepadanya.

- Memerintahkan perangkat desa/kepala dusun untuk menyelidiki kasus perkara, dengan menghubungi para pihak yang bersangkutan.

Mengundang para pihak yang berselisih, para saksi, untuk didengar keterangannya.

Membuka persidangan dengan menawarkan perdamaian di antara

Otje Salman Soemadiningrat, 2002, Rekonseptualisasi Hukum Adat Kontemporer, Alumni, Bandung, hlm.43. 
kedua pihak, jika dipandang perlu dapat dilaksanakan sidang tertutup.

- Memeriksa perkara, mendengarkan keterangan saksi, pendapat para sesepuh desa, kepala dusun yang bersangkutan dan lainnya. ${ }^{10}$

Carta penyelesaian delik adat yang dilaksanakan oleh kepala desa tidak jauh berbeda dari cara penyelesaian kepala adat, yaitu bukan mencari siapa yang benar dan yang salah tetapiberusahauntuk mewujudkan kedamaian antara kedua pihak dan pulihnya kembali keseimbangan yang terganggu.

Kasus yang terjadi di Dusun Tegeh ternyata Pengadilan Negeri tidak mempertimbangkan atau memutuskan mengenai kewajiban adat terhadap pelaku tindak pidana adat gamia gamana. Hal ini didasarkan pada ketentuan yang tercantum dalam Pasal 285 KUHP dan Pasal 294 (1) KUHP yang menurut ancaman pidananya sesuai Pasal 10 KUHP tidak secara tegas mencantumkan pidana kewajiban adat. Karenanya masyarakat desa adat yang tertimpa kasus delik adat gamia gamana di desa selat dan desa purwakerti mengambil langkah-langkah penyelesaian secara adat terhadap kasus tersebut.

Desa adat selat oleh lembaga adatnya berdasarkan awig-awig menyelesaikan perbuatan pidana gamia gamana tertuang dalam Pasal 48 ayat 3 huruf a menyatakan "berzina yang termasuk lokika sanggraha dan gamia gamana yang sampai ketahuan/ ditangkap oleh istri dilaporkan kepada prajuru adat akan dikenakan sanksi denda terhadap kedua pelaku melalui musyawarah desa”. Sedangkan untuk desa purwakerti

10 Hilman Hadikusna, 1992, Pengantar Ilmu Hukum Adat Indonesia, Mandar Maju, Bandung, hlm.245. hukum untuk menyelesaikan gamia gemana belum diatur dalam awig-awig hanya melalui musyawarah desa saja.

Penyelesaian pelanggaran pidana adat gamia gamana pada desa adat selat dapat diuraikan sebagai berikut:

a. Melakukan pembayaran denda kepada desa berupa dua karung beras dan 2 pasang kelapa muda.

b. Melaksanakan upacara mecaru balik sumpah guna menyucikan kembali alam yang dilakukan oleh pandita

c. Diasingkan dari desa adat dan tidak diperkenankan kembali mekrama desa, setelah pelaku selesai menjalani masa penahanan di lembaga permasyarakatan.

\section{PENUTUP}

\subsection{Kesimpulan}

1. Pertimbangan nilai-nilai agama hindu dalam praktek peradilan oleh putusan hakim di pengadilan singaraja belum dilaksanakan,padahalpengenaansanksi adat sangat diperlukan untuk menjaga keseimbangan akibat gangguan yang terjadi. Undang-Undang Dasar Negara Pasal 18 B ayat 2 dan Pasal 5 ayat (3) sub b UU darurat 1 tahun 1951 serta Pasal 50 ayat (1) aturan kekuasaan kehakiman mendukung penjatuhan sanksi pidana adat baik secara eksplisit maupun implisit. Hal tersebut terlihat dalam pertimbangan amar putusan perkara perbuatan pidana adat di PN Singaraja.

2. Upaya yang dilakukan untuk menyelesaikan delik adat di bali pada kasus gamia gemana adalah upakara mecaru balik sumpah dan mepepada oleh desa adat sudaji. Penjatuhan sanksi 
adat tersebut mengacu pada awigawig desa adat masing-masing dengan disertai paruman atau pertemuan guna untuk memantapkan dan memberi keadilan bagi si pelanggar.

\subsection{Saran}

1. Hakim dalam memutuskan perkara adat perlu mempertimbangkan sosioreligius masyarakat setempat sebagai bentuk langkah antisipatif futuristik sehingga tercapainya keseimbangan cosmis dengan tidak melupakan ketentuan pemidanan sebagaimana diatur dalam KUHP.

2. Perlu adanya tindakan tegas berupa pengusiran dari desa adat setempat dan diberhentikan menjadi warga desa (krama desa) apabila tidak memenuhi kewajibannya untuk melaksanakan upacara penyeimbangan alam akibat penyimpangan perilaku si pelanggar.

\section{DAFTAR PUSTAKA}

\section{Buku}

Amirudin dan Zaenal Asikin, 2006, Pengantar Metode Penelitian Hukum, PT. Raja Grafindo Persada, Jakarta.

Hadikusna, Hilman, 1992, Pengantar Ilmu Hukum Adat Indonesia, Mandar Maju, Bandung.

Pudja, I Gede dan Tjok Rai Sudharta, 1978, Manawa Dharma Sastra (Manawa Dharmacastra, Ditjen Bimas Hindu dan Budha, Jakarta.

Rahardjo, Satjipto, 1998, Pengertian Hukum Adat, Hukum yang Hidup dalam Masyarakat, Binacipta, Bandung.

Soemadiningrat, Otje Salman, 2002, Rekonseptualisasi Hukum Adat Kontemporer, Alumni, Bandung.
Soepomo, 1983, Bab-Bab Tentang Hukum Adat, Pradnya Paramita, Jakarta.

Sudarto, 2003, Hukum Pidana, Alumni Cet. 4, Bandung.

Sutha, I Gusti Ketut, 1987, Bunga Rampai Beberapa Aspek Hukum Adat, Liberty, Yogyakarta.

Widnyana, I Made, 1993, Kapita Selekta Hukum Pidana Adat, Eresco, Bandung.

Windia, Wayan P. dan Ketut Sudantra, 2006, Pengantar Hukum Adat Bali, Lembaga Dokumentasi dan Publikasi Fakultas Hukum Universitas Udayana, Denpasar. 